Article

\title{
Planning for 1000 Years: The Råängen Experiment
}

\author{
Peter Pelzer ${ }^{1}$, Roger Hildingsson ${ }^{2, *}$, Alice Herrström ${ }^{2}$ and Johannes Stripple ${ }^{2}$ \\ ${ }^{1}$ Department of Human Geography and Spatial Planning/Urban Futures Studio, Faculty of Geosciences, Utrecht University, \\ 3584 CB Utrecht, The Netherlands; E-Mail: p.pelzer@uu.nl \\ 2 Department of Political Science, Lund University, Box 52, 22100 Lund, Sweden; \\ E-Mails: roger.hildingsson@svet.lu.se (R.H.), alice.herrstrom@svet.lu.se (A.H.), johannes.stripple@svet.lu.se (J.S.) \\ * Corresponding author
}

Submitted: 2 August 2020 | Accepted: 4 December 2020 | Published: 26 March 2021

\begin{abstract}
While traditional forms of urban planning are oriented towards the future, the recent turn towards experimental and challenge-led urban developments is characterized by an overarching presentism. We explore in this article how an experimental approach to urban planning can consider the long-term through setting-up 'conversations with a future situation.' In doing so, we draw on a unique experiment: Råängen, a piece of farmland in Lund (Sweden) owned by the Cathedral. The plot is part of Brunnshög, a large urban development program envisioned to accommodate homes, workspaces, and world-class research centers in the coming decades. We trace how Lund Cathedral became an unusual developer involved in 'planning for thousand years,' deployed a set of art commissions to allow reflections about values, belief, time, faith, and became committed to play a central role in the development process. The art interventions staged conversations with involved actors as well as publics geographically and temporally far away. The Råängen case illustrates how long-term futures can be fruitfully brought to the present through multiple means of imagination. A key insight for urban planning is how techniques of financial discounting and municipal zoning plans could be complemented with trust in reflective conversations in which questions are prioritized over answers.
\end{abstract}

\section{Keywords}

art; deep-time organizations; experimentation; long-term; planning; Sweden

Issue

This article is part of the issue "Urban Planning by Experiment" edited by Christian Scholl (Maastricht University, The Netherlands) and Joop de Kraker (Maastricht University, The Netherlands).

(C) 2021 by the authors; licensee Cogitatio (Lisbon, Portugal). This article is licensed under a Creative Commons Attribution 4.0 International License (CC BY).

\section{Experimenting with the Long Term}

A key characteristic of planning is that it "embrace[s] an orientation towards the future" (Hillier \& Healey, 2010, pp. 12-13). Planners make decisions in the present with long-term effects. However, planners have not always been successful in letting their long-term plans come to fruition-for example, many implementations of the famous Dutch spatial planning visions had less of an influence than their originally stated objectives (Hajer \& Zonneveld, 2000). Furthermore, plans often result in unintended consequences, a case in point being modernism's failure to anticipate the detrimental effects of separated functions for social interaction (Berman, 1983; Scott, 1998).

A decisive break from this kind of top-down and rigid engagement with spatial futures is the set of urban experiments that emerged from both urban policy and academic research in the early 2010s. Urban experimentalism builds on key insights from the field of sustainability transitions, according to which the shift to urban sustainability is the result of experimentation in 'niches' or local practices, in which new ideas can be tested and matured (e.g., Evans, Karvonen, \& Raven, 2016; Markard, Raven, \& Truffer, 2012). Summarizing these developments, Sengers, Wieczorek, and Raven (2019, p. 153) 
define an experiment as "an inclusive, practice-based and challenge-led initiative, which is designed to promote system innovation through social learning under conditions of uncertainty and ambiguity." Over the last two decades, experiments have emerged in different sectors, including mobility, renewable energy, waste, the provision of social services, as well as in urban development projects.

Cities are increasingly the site of these experiments. Economists and economic geographers (e.g., Florida, 2002; Glaeser, 2011) already emphasized the innovative potential of cities in the 1990s and early 2000s, because cities are diverse ('Jacobs externalities') and have scale ('agglomeration externalities'). The urban experimentalist approach builds on cities' innovative potential, but is interested in outcomes beyond economic growth such as social justice or the mitigation of climate change. Since the early work on climate experiments by Bulkeley and Castán Broto (2012), the field of urban experiments has broadened both its thematic focus (to include, e.g., food, mobility, and post-capitalist initiatives) and conceptual basis. The latter now includes a range of typologies about experiments themselves, the role of local governments, and the local environments in which experiments play out (e.g., Caprotti \& Cowley, 2016; Kronsell \& Mukhtar-Landgren, 2018; Torrens, Schot, Raven, \& Johnstone, 2019).

Whereas the range of interests has broadened, learning has remained a central premise of urban experiments. Urban experiments are not just meant to test a specific solution in a specific context, but rather have the potential to set something in motion-cognitively, culturally, politically, institutionally-beyond that particular instance. As Fuenfschilling, Frantzeskaki, and Coenen (2019, p. 225) put it: "Experimentation is about de-risking new solutions or approaches by learning about and with them in an open and safe space." Importantly, learning in experiments is not only conceived as an individualistic and cognitive endeavor, but as a collaborative process, typically referred to as 'social learning.' As such, the learning process is also part of the transformation of the socio-technical system in which an experiment is embedded (see, e.g., Brown \& Vergragt, 2008; Bulkeley \& Castán Broto, 2012; Fuenfschilling et al., 2019).

Although we acknowledge and see the merit of the flexible, reflective, and experiential process of experimentalism, in this article we argue that it might also obfuscate what traditionally was the chief concern of spatial planning: the long term. For all the shortcomings of blueprint planning and modernism, these approaches did explicitly engage with the long-term implications of planning issues. Whereas many urban experiments deal with long-term themes such as energy supply, biodiversity, or climate change, long-term considerations typically receive little attention. We analyzed 22 articles on urban experiments and none of them explicitly engaged with the long term (see the Supplementary Material).
Indeed, one explanation for the surge in urban experiments is that its effects can be directly observed and adaptations can be made in a kind of trial-and-error way. Yet this benefit comes with a trade-off: In experiments it becomes much harder to look beyond pressing shortterm issues to reflect on long-term implications.

Caney (2019) explains why 'harmful short-termism' is problematic yet so ubiquitous. According to Caney, it is challenging to deal with issues that will chiefly affect future generations-such as climate change-because they manifest themselves much less prominently in the present. Reasons for short-termism include a political system in which elected officials represent only the current generation, the way in which the media are organized, and the psychological complexities of thinking beyond the present. Caney develops a range of solutions (focusing on political reforms such as the development of future councils) and underlines the importance of artists in imagining the future. He concludes:

We need to re-imagine ways of organizing our political life to make the 'future' salient and visible, to jolt us out of our fixation on the present, and to induce us to look ahead and give the 'future' its due. (Caney, 2019, p. 15)

In this article we are interested in exploring an experimental approach to spatial planning that 'gives the future its due.' This is a crucial question that in our view is still underexplored both in planning practice and in scholarly research. As such, the aim of this article is to explore how an experimental approach to urban planning can engage with the long term. In doing so, we will draw on insights from a case study involving an ongoing planning experiment framed by the idea of planning for a thousand years (see the Supplementary Material for the case study methodology). The case is an urban development project, called Råängen, run by the Cathedral of Lund, Sweden. Their thousand-years framing raises intriguing questions for urban planning and experimentation: Could planners envisage such a long-term horizon? How do they even begin to engage with a situation so far in the future?

\section{Conversations with a Future Situation}

To begin with, it is helpful to look more closely at some of the ideas of pragmatism that have underpinned much planning theory since the so-called communicative turn in the 1990s (e.g., Healey, 1992a). Here, experimentation also plays a key role in conceiving planning, albeit in a somewhat different way. The application of pragmatism to planning emphasizes how planning is a reflective practice characterized by situated judgment. Empirical research working in this tradition has paid close attention to the considerations and experiences of practitioners (Healey, 1992b, 2009; Hoch, 1994). The philosophy of pragmatism is not easy to summarize, but it is typically 
described as a "philosophy of what works," one that does not aim to discover the truth but rather makes use of the craft of situated judgment in a continuous process (Healey, 2009). One of pragmatism's founders, John Dewey, maintained that means and ends are unstable and in a continuous interaction, which requires an unceasing process of reflection.

Starting from this premise, Schön developed Dewey's work into a perspective on learning with important implications for both planning theory and recent urban experiments (e.g., Schön, 1983, 1992). Learning is, in Schön's perspective, largely a process of reflection: Not so much learning how the world works through books as making sense of concrete situations in practice. Schön (1992) identifies three stages of increasing complexity in a reflective practice. First, knowing in action: In this stage, situations are not problematic, and one is equipped to find the right course of action. No reflection on what to do is required. Second, reflection in action: One encounters a problematic situation, but one reflects during this situation on a course of action. Reflection in action is difficult to record, because "we tend to 'wipe it out' as soon as it is over, like the error one makes and quickly forgets on the way to discovering the solution to a puzzle" (Schön, 1992, p. 125). Third, and most relevant for the purposes of this article, is what Schön refers to as a metaphorical conversation-with-the-situation. As he puts it:

Here, an inquirer, in transaction with the materials of a situation, encounters surprise in the form of 'back-talk' that momentarily interrupts action, evoking uncertainty. The inquirer goes on to transform the situation in a way that resolves uncertainty, at least for the moment. (Schön, 1992, p. 125)

In this article, we ask how it is possible to engage in conversations with a future situation, whereby 'future' is conceived as the long term and includes, for instance, attention to the needs of future generations or a 'deep-time' focus (e.g., Caney, 2019; Hanusch \& Biermann, 2020; Krznaric, 2020; World Commission on Environment and Development, 1987). This requires a redirection of Schön's work, which has focused mostly on past situations. For conversations with a future situation, we argue three dimensions to be of particular relevance for reflecting on the long term.

First, the tangibility of the future refers to the means through which a yet unknown future is presented. Reflection occurs through different senses and through different carriers (Candy \& Dunagan, 2017; cf. Dewey, 1938). Whereas numbers and written analyses are still central to planning decisions, scholars building on design studies maintain that the future should be brought to the present more experientially through, among other things, visceral and embodied interventions (e.g., Bendor, Maggs, Peake, Robinson, \& Williams, 2017; Candy \& Dunagan, 2017; Pelzer \& Versteeg, 2019).
Whereas in urban experiments such embodiment typically occurs more naturally, by being part of an on-theground situation, experiencing the long term requires a more careful staging of "the reflective imaginative conception and comparison of alternative actions in the face of some problem [that] enables humans to move beyond risky trial-and-error learning on the ground" (Hoch, 2016, p. 7).

Second, conditions for opening up the long term: Attention to the long term is not distributed evenly across time or institutional contexts. The extent to which long-term considerations can be reflected depends not only on the dramaturgy of a conversation (Hajer, 2009), but also on the phase in the planning process. For instance, in the planning of a new tramline, the long-term future is considered through different scenarios and cost-benefit analyses. However, once the decision is made the attention of the actors involved tends to focus on operational and short-term matters. In this regard, drawing on a United Nations conference, Mische (2014, p. 433) introduces the concept of 'sites of hyper-projectivity' as "arenas of heightened, future-oriented public debate about contending futures, such as those taking place in communities, social movements, and policy arenas." Contrary to Mische's conception, in planning such sites are not necessarily public; the long-term future can also be discussed behind the scenes. For instance, in 'deep-time organizations' (Hanusch \& Biermann, 2020) reflections about the long term do not only occur in public debates, but are also part of the internal culture, practices, and the very organization of their operations. Hanusch and Biermann characterize deep-time organizations by their extreme longevity, both in terms of their long existence (centuries or more) and their engagement with long-term challenges. Typically, such deep-time organizations are associated with a timeless purpose, often linked to common goods and public values. They tend to address issues and provide services that are "overwhelmingly either basic human needs or transcendental" (Hanusch \& Biermann, 2020 , p. 29), the latter being exemplified by religious organizations such as churches. Another key characteristic of deep-time organizations is that they are well connected to the surrounding society and have the capacity to adapt to and incorporate external changes in their operations. Whereas Hanusch and Biermann are chiefly interested in explaining the longevity of deep-time organizations, we are concerned with the practices of a deeptime organization such as a millennial cathedral. Such practices include their reflections about the future and the kind of decisions that are being taken in light of long-term concerns.

Third, interactions between different timescales: Reflection about the long term often centers around how short-term decisions have long-term implications. In some instances, this is the result of a very careful scenario planning or visioning process. In other instances, decisions are taken in the 'heat of the moment,' for 
instance under public or political pressure, but have long-term repercussions. In spatial planning, the concept of path dependence is of particular relevance: Once land use, infrastructure, or even institutions have taken a certain form, they are difficult to radically change again (e.g., Sorensen, 2015). Thus, there is an irreversibility in planning that puts constraints on what kind of subsequent planning decisions are possible.

\section{The Råängen Experiment}

\subsection{Planning for Thousand Years}

Our aim is to rethink the way that towns are developed by introducing an arts programme that will become a tool for conversation, critical debate and engagement before any building work begins....The [Råängen] development will address 21st century challenges by creating a sustainable and socially responsible working and living environment that is able to meet people's needs for the next 1,000 years. (Råängen, 2020)
This statement is taken from the website of the Råängen (the raw meadow) project in Lund, Sweden. At its heart is a 12-hectare plot of land owned by the Swedish Church through its local cathedral organization. Råängen is part of the large-scale development in Brunnshög (around 270 hectares), which will become a new neighborhood in the northeast part of the city (see Figure 1). In addition to housing, the area will include a 'Science village' with two large research facilities: the European Spallation Source and MAX IV, a synchrotron radiation facility. By 2040 the area of Brunnshög is envisioned by the city to host forty thousand residents and knowledge-intensive workers in a dense urban environment. The area has, like much recent Scandinavian urban development, high sustainability standards, which include a tram line, excellent biking infrastructure, a low-temperature district heating system utilizing excess heat from the research facilities, low-energy houses, underground waste management systems, and urban greening.

The plot of land of Råängen is financially and institutionally linked to the cathedral building in the city center. The Cathedral of Lund dates back to at least the

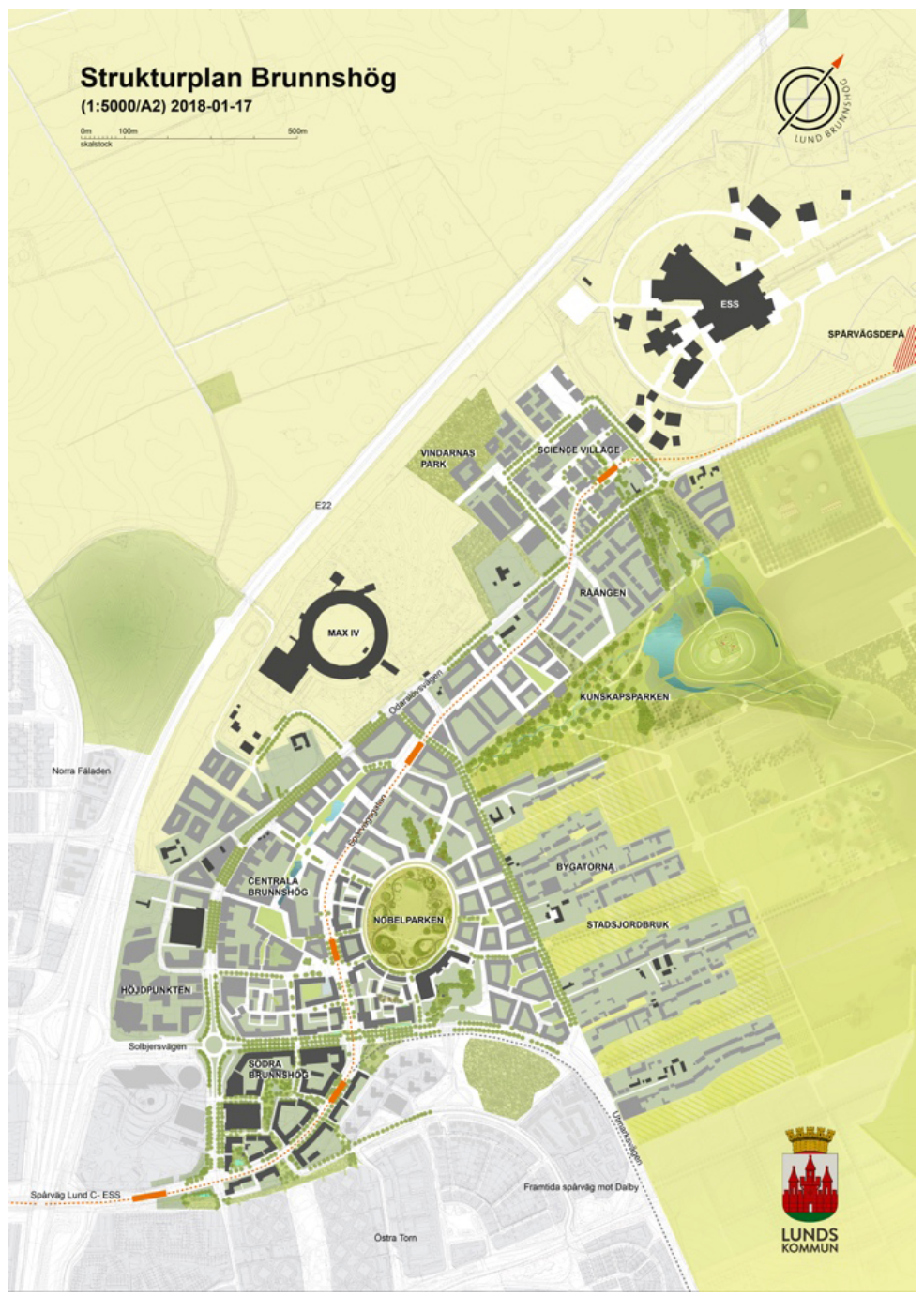

Figure 1. Map of Brunnshög development area. Source: Lund Municipality (2020). 
year 1123 when the first altar was consecrated. It was originally a Catholic church but has been Protestant since the mid-16th century. The history of Lund Cathedral is reflected in the thousand-year time frame, which has long been a part of the self-identity of the cathedral. Their treasurer, who plays a key role in the Råängen development, told us a story that illustrates this: When he was first introduced to his job by the bishop, she emphasized how they all share a responsibility to care for both their history and their future. In particular, she urged him to think about the future; recognizing that the cathedral has been here for a thousand years, they should consider what it implies for the church to be around for another thousand years. So, while not being an idea newly conceived for Råängen, this time frame was incorporated in the objectives for the project.

In considering this long-term perspective, the cathedral's decision makers did not articulate a clear vision, but rather developed a reflective and gradual process with the cooperation of a variety of artists, architects, writers, and thinkers. As such, Råängen can be considered a 2,000-year program (see the timeline in Figure 2). This, according to the curator, might sound "a bit crazy" (Art and Christianity, 2020), but it allows for the recognition of the work and traditions of the past while projecting themselves into an unknown future.

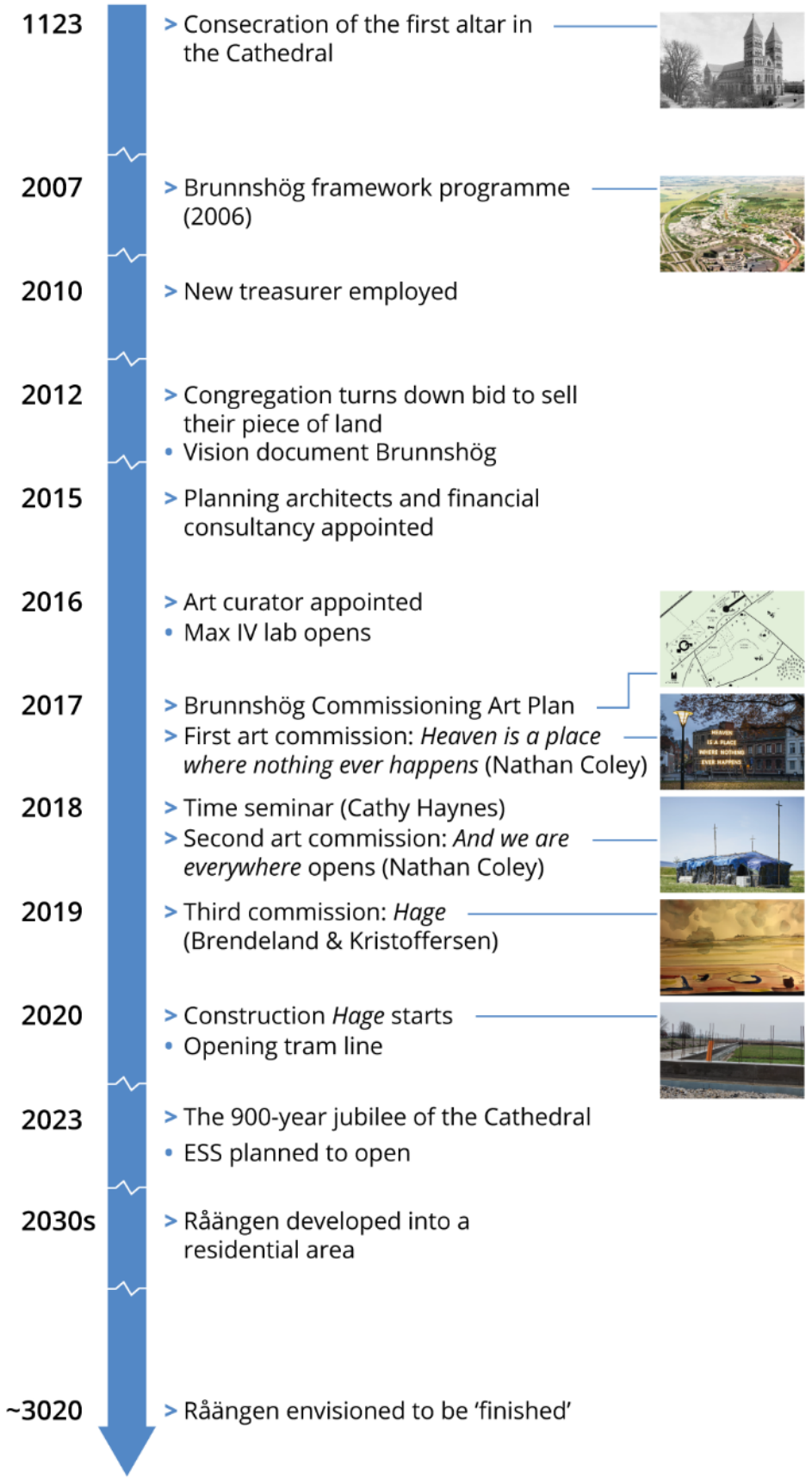

Figure 2. Timeline of the Råängen development. 


\subsection{A Church Decides to Become a Developer}

The story begins when the city approached the cathedral managers with a bid to buy a piece of their land in 2012. At that time, the cathedral's management had recently undergone organizational changes. Their property management committee had appointed a new chairman, a former banker, and recruited a new manager for the treasury, a former farmer. New to their positions, both of them were reconsidering the cathedral's property management, and the Brunnshög development spurred an interest in exploring new ways to responsibly enhance their financial returns. Normally, the Swedish Church would sell off their land to the municipality for this kind of urban development. However, despite their relaxed attitude, as a deep-time organization, toward short-term financial rewards, the cathedral decided not to sell. As one board member put it:

The main reason in the start was that if we sell the land to the municipality, we get the price for farmland. We know that if we do develop it ourselves, we can make 10 to 20 times that price.....After we had decided, no we won't sell to the community, we started the process: What will we do with that? [The purpose is] not only to make money.

Or, as the treasurer summarizes it somewhat differently: "The theological values are important, but we have to have money to actually finance them with." Thus, while the decision not to sell the land was backed by the more financially experienced members of the board, financial concerns were not the sole reason why they decided to also develop the land themselves. In the words of the treasurer, they saw it as "a value development," which cared for other values central to the church. The chaplain explained that in one of the board meetings they reflected on the long history of the cathedral and saw an opportunity in the Brunnshög development to address issues like climate change, immigration and building a city together with others. At that time, however, the cathedral was not sure how to convert these convictions into ideas that would be useful for spatial planning. To support them in discovering these values and to help them with the planning process, White Arkitekter was contracted in 2015. They were tasked with a scoping exercise "to define the parameters of the Church's development in Brunnshög" (Fernie, 2017) and to compose a sustainability program for the area. The scoping involved a series of conversations with the cathedral managers to explore what values were most important to the church. As emphasized by one of the architects, this conversation resulted in a value-based planning approach structured around three guiding concepts: landskap (landscape), grannskap (neighborhood) and värdskap (hostship).

To strike a balance between the spiritual and managerial arms of the cathedral organization, a twin leadership was set up for the project, chiefly represented by the chaplain and the treasurer. These leaders view the endeavor of Råängen as a learning process characterized by raising questions and challenging suppositions, all as part of a continuous reflection on the role of the church in urban planning. Importantly, while this process has no clear vision, it is placed against a 'backdrop' of religious beliefs and sacred conceptions of time. For instance, the treasurer mentioned how he invited construction workers to the cathedral and told them how their work would become part of "the values of the church and the longevity of the house." In a similar vein the chaplain refers to this 'backdrop' as a "kind of mind map, or an image, to remind us about this social thinking around urban planning."

\subsection{Heaven Is a Place Where Nothing Ever Happens}

After deciding to become an urban developer and defining the core values directing their plans, the next step for the Råängen team was to initiate a reflective dialogue with various actors. This was done by launching an art and architectural program that involved a series of temporary art commissions. These commissions offered entry points into reflections on fundamental values such as religious convictions, time, and the church's role in society (Fernie, 2017). The renowned artist Nathan Coley was contracted for two temporary art installations in 2017 and 2018. The first exhibit brought to Lund an existing art work by Coley: Heaven Is a Place Where Nothing Ever Happens, a light sculpture referring to the Talking Heads song, which was installed adjacent to the cathedral apse for five months (see Figure 3). Its placement in the middle of Lund's medieval cityscape and its somewhat seductive character helped attract attention and develop a conversation with local residents and students, as well as on social media.

The Råängen team also arranged public events and seminars with Nathan Coley and other artists. For example, the English artist and writer Cathy Haynes was invited to reflect on the concept of time (Haynes, 2018). In April 2018, a public 'time seminar' was arranged in the cathedral (see Figure 4), in which Haynes and the chaplain reflected upon "the unique nature of longterm projects and the concepts of earthly and heavenly time" (Art and Christianity, 2020). At the seminar they considered how Western conceptions of time are often portrayed similarly across contexts, while sacred time "has a more complex structure, form, variety and rhythm than the standard tick-tock or the straight line of progress" (Haynes, 2018). Religious conceptions of time do, indeed, conflict with linear notions of land management and urban development. Yet, the linear and relatively short-term perspective of time is also present in the Råängen experiment, which became apparent in our interview with the property asset consultant. Talking about the calculations of future costs and revenues, he mentioned his quantitative analyses to allow for alternative development models, which would, for example, 


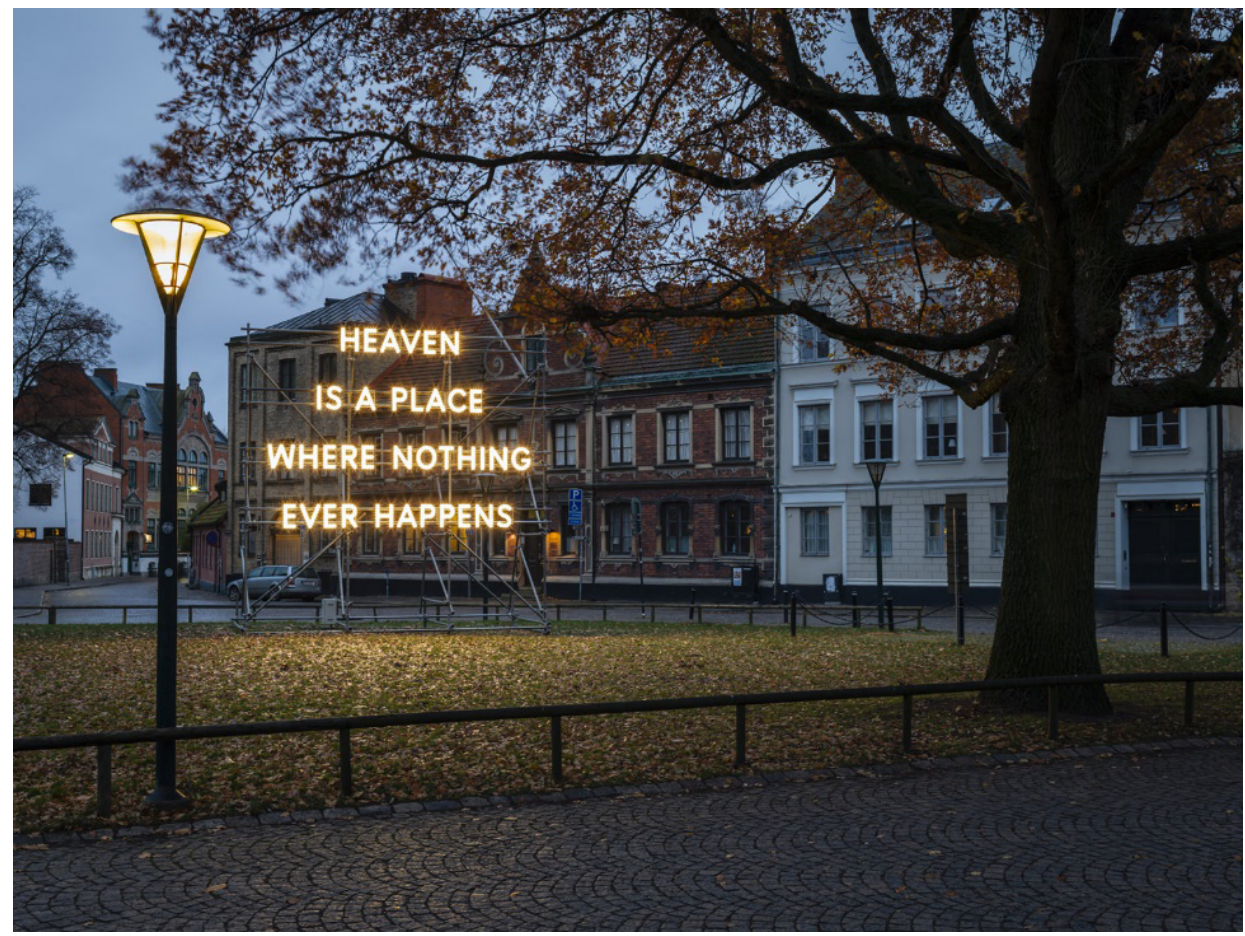

Figure 3. Heaven Is a Place Where Nothing Ever Happens, by Nathan Coley, Lund 2017-2018. Source: Peter Westrup.

allow private parties to take most of the profits for the first decades.

\subsection{And We Are Everywhere}

Coley's second commission, And We Are Everywhere, had a different geography. It was located at Råängen in the middle of grassland (see Figure 5). This first physical intervention in the area was meant to challenge existing assumptions about hostship, migrants, and the role of the church in the new development. The intervention consisted of a large sculpture built from materials used in improvised migrant camps such as plastics and wooden boards. While it was praised in the local press for bringing social aspects to the planning and housing debate (Sommar, 2018), it was far from an easily accessible work of art. As the curator stated:

It was aesthetically disturbing (it didn't look like art!) and asked uncomfortable questions about Sweden's

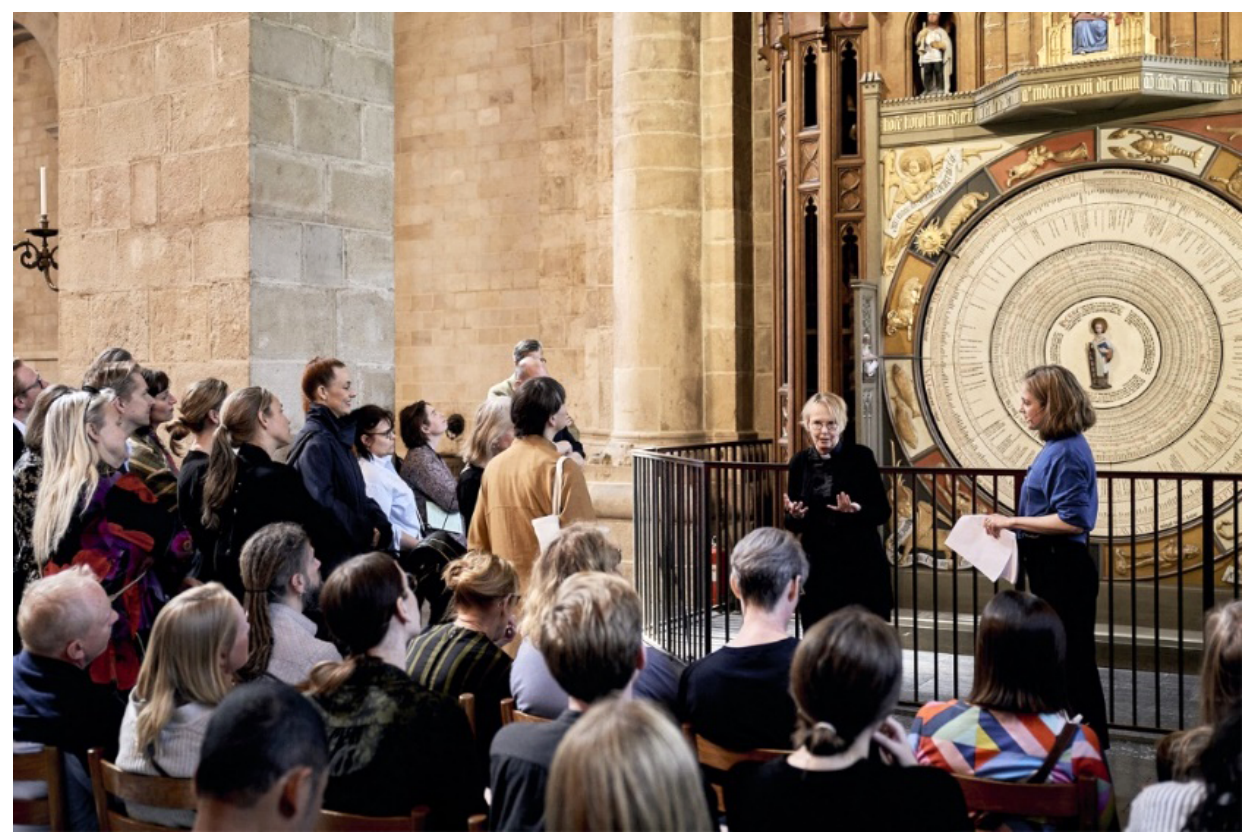

Figure 4. Time seminar in Lund Cathedral, 18 April 2018. Source: Peter Westrup. 


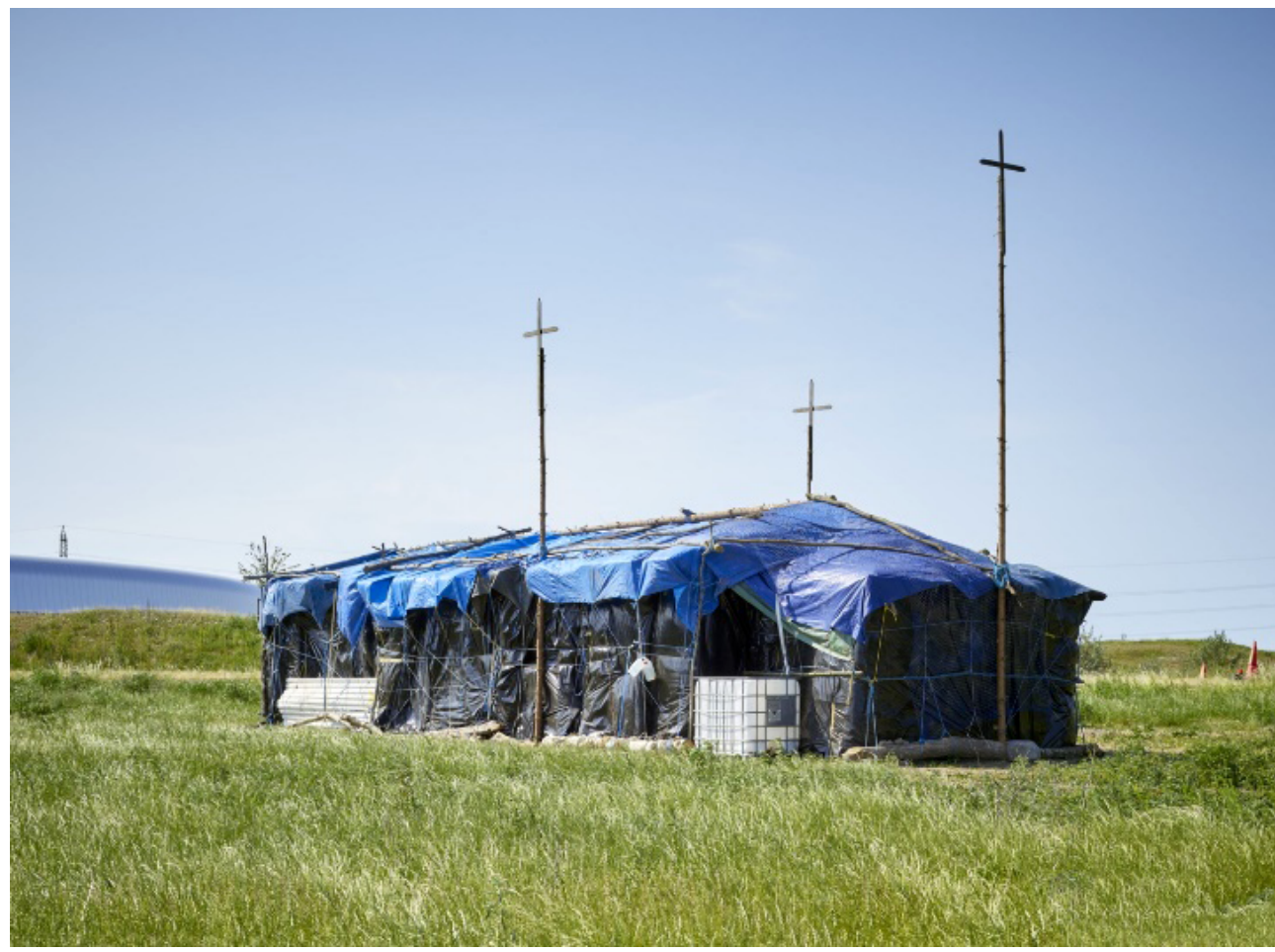

Figure 5. And We Are Everywhere, by Nathan Coley, Lund 2018-2019. Source: Peter Westrup.

relationship to immigration, people with no home, the church's place in the land. We were intrigued by the silence with which it was greeted, but of course, this was all part and parcel of people 'expressing' their discomfort.

Another respondent was less appreciative of this "silence" and felt the project could have done better to activate the land and engage with the local public. For the core cathedral team, And We Are Everywhere was of great importance, however. In a number of conversations that accompanied the piece, Coley pushed them to reflect on their ambitions and, in particular, shaped their commitment to create a neighborhood for all in Råängen. As the chaplain reflected on the influence of this intervention:

The absolute strongest impression it had on me, afterwards, was that we were strongly put into the area of discussion of refugees and homelessness. How should we organize our societies when we know that there will be even more people running away from their countries because of climate change, wars, and so on?

According to the curator, the objective of the temporary art commissions was to let art shape the conditions for further development at Råängen. Coley's commissions functioned as a means to provoke, defamiliarize, and challenge the suppositions of the church and turned out to be invaluable to the cathedral. The artistic interventions, as well as conversations both in small settings and in public seminars, helped the Råängen team to artic- ulate the project's principles and objectives, although what this involved was not always clearly expressed by our interviewees. The treasurer emphasized how he needed time to reflect in order to understand what Råängen is about and what the conversation with the future situation meant for him:

I think it is not so obvious for people outside looking at the project to, but eventually they will see that Heaven stood here, And We Are Everywhere was put up there and then Hage [the third commission] will come, and then this, they see the sequences and eventually the first house will in some way be a commission.

The treasurer emphasized how the artistic interventions not only provoked reflections on the role of the church but also helped to craft a story about the urban area yet to be built. A similar claim is made by one of the architects: "So, what we were doing is sort of setting up this story for developers or builders or potential residents to kind of buy into."

This should be understood in the context of Råängen being an almost 'empty' area in need of a future story. The previous farmland "has an abstract, almost invisible history," as emphasized by the curator (Fernie, 2017, p. 8). By facilitating a continuous conversation with the future situation and documenting the process, imaginatively and on site, the Råängen project is crafting its own story, which may appeal to its future community and inhabitants as well as various stakeholders and developers. 


\subsection{Hage}

The third commission is of a different nature. In contrast to Coley's temporary projects, the Hage (Garden) commission represents the first permanent installation on site, a public space currently being constructed in the form of a garden with a communal area (see Figure 6). Initially, the intention was to "construct a series of temporary installations in the landscape that would take people on a journey through Råängen. But after a few meetings and site visits and conversations...we agreed that this was a good option to build something permanent" (Art and Christianity, 2020). The commissioned Norwegian architects Geir Brendeland and Olav Kristoffersen came up with the idea to build a public space, configured as an enclosed garden with brick walls on three out of four sides opening up to the landscape outside and a pergola with a large table for picnics and gatherings. While the garden relates to Christian notions of stewardship, its construction as a public space also allows the church to invite people to come to Råängen and create a relationship with the site.

Hage is one step in a sequence of commissions that functions as a bridge to the development of housing on the site. This sequence serves as both a form of storytelling and a physical intervention, with the idea of a residential area emerging around the public garden, which will then "shift from being an object in the landscape to a local park for a new community" (Råängen, 2020). In one sense, letting the first physical investment take the shape of a public space is a statement, shifting emphasis from visitors to future residents. Simultaneously, Hage is still an interrogation of values and is driven by the philosophical concept of metamorphosis, from rural farmland to urban residential area. In another sense, its permanence will inevitably influence the urban transformation around it and direct further sequences of urban experimentation, as emphasized by one of the architects: "I think Geir [Brendeland] described it as...a grain of sand. You know, this sort of small thing and hopefully things get built around it."

\subsection{The Shovel in the Ground}

The interviews and emerging insights raise questions about how Råängen will develop in the coming decades and centuries. As the treasurer remarked, at a certain point "the shovel has to go into the ground," meaning that sometime in the coming decade buildings will start appearing, according to the planning requirements for the area and because Råängen needs to start seeing financial returns in order to maintain the cathedral building. Thus, while Råängen has a slower and more reflective development process than the rest of Brunnshög, it is likely that the spatial structure will become more concrete through drawings, financial analyses, and physical interventions, which will narrow the possibility space for every step in the urban transformation of the area.

Furthermore, as the planning process progresses, the Råängen project's multi-layered and complex relationship with the municipality will intensify. While the collaboration has been constructive-as, for example, when the municipal planning council approved a building permit for Hage despite missing the required detailed zoning plan-it also has become clear that Råängen does not fit the development logic of Brunnshög, with its clearly defined objectives and the necessity to build infrastructure quickly. While one of the city planners referred to

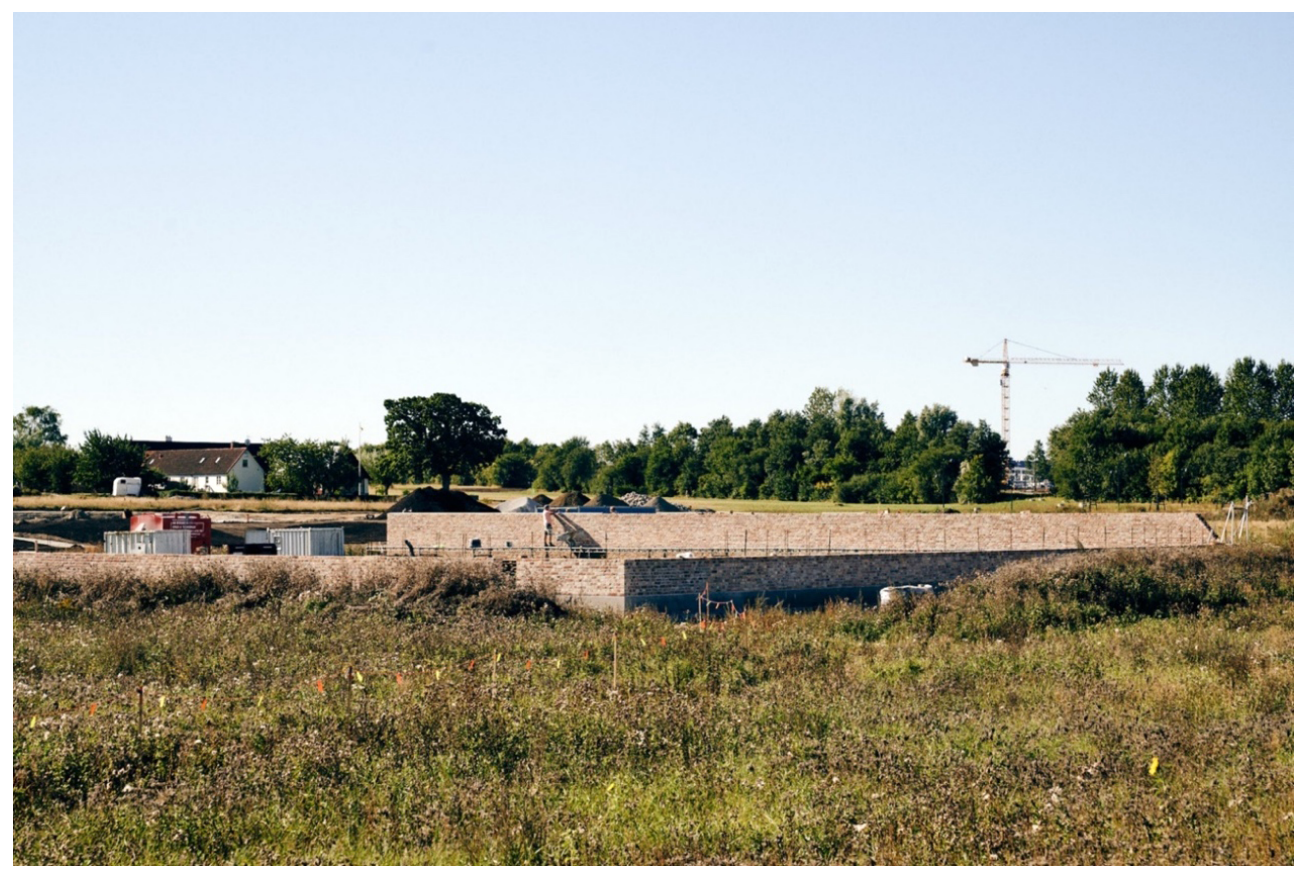

Figure 6. Construction of Hage developed by Brendeland \& Kristoffersen. Source: Peter Westrup. 
Råängen as a positive "infection," for the most part the municipality is unintentionally ignorant about the principles of the Råängen project. An illustrative example is the boundary to the neighboring park. In its zoning plan, there is a noticeable bump in an otherwise straight border. The Råängen team asked for a less straight line between the properties in order to connect to the park in a flexible manner. However, in response to their request, city planners simply curved the border somewhat and adapted it to an existing pipe running through the landscape-much to the shock of the treasurer, who felt the municipality did not understand the spirit of the process. Perhaps this is a trivial example. However, it could be that this 'infection' is still in an early stage and will grow as the spatial structure of Råängen emerges and starts to interact with the rest of Brunnshög. From that moment onwards it will become much harder for the municipality and other actors involved to (implicitly) ignore the interventions in Råängen.

\section{Reflections about the Long Term}

In order to draw broader insights from the Råängen case, we have structured the following discussion around the three concepts of tangibility, conditions, and interaction between time scales.

\subsection{Tangibility}

It is noteworthy that Råängen's engagement with the long term started with a short-term and market-driven event: through the Brunnshög plans, the cathedral's farmland turned into property with potentially very high financial value. From that moment onwards Lund Cathedral chose a unique planning approach, markedly different from usual Swedish planning practice. The long-term future was rendered tangible through two approaches. First, the tripartite value structure of landscape, neighborhood, and hostship was selected to guide the planning process. The coming decades will shed more light on what this value set means for the planning decisions that will be taken in Råängen. Second, framing the project as planning for another thousand years prompted an interrogation of the very nature of time. The future was rendered tangible not as some kind of end state, but as a process always in the making. The church managers chose not to immediately begin developing visions for their land - through a spatial design studio or a scenario planning approach-but rather commissioned artists and architects to stage interventions that sparked a conversation about the future. Coley's commissions primarily resulted in important internal reflections among the church managers. This did not lead to concrete courses of action so much as it established a shared understanding about the benefits of a reflective and open approach to spatial planning. Hage, the final commission that we studied, can also be considered a careful and reflective step in this process. However, as this commission will also physically alter the area, it gives a different dimension to the tangibility of the long term. It has become difficult to imagine the future of Råängen without a public space in its center, around which subsequent steps in the urban transformation will take shape.

In terms of tangibility, it is also interesting to consider how different presentations of the future interact. Internally, this could be seen in the peaceful coexistence between the more traditional financial analyses assessing the potential future revenues of the land and the artistic and architectural commissions. When we asked, somewhat naively, during the interview whether his analyses could reflect a time span of a thousand years, the financial analyst indicated that this would not make any sense given the uncertainties that come with projecting so far ahead. However, whereas these financial analyses would typically be leading discussions about what to do, here they were considered one part of the conversation, less important than the tripartite value set. Thus far, the interactions between different presentations of the future of the overall Brunnshög development and the Råängen development have been fairly limited, although a few small conflicts suggest Råängen might act as a 'positive infection' for the whole area and for the municipality at large. As the planning process continues to unfold in the coming decades, it will be interesting to study the interaction between the Råängen experiment and the wider Brunnshög development. Will the artistic commissions remain inquisitive and philosophical, or will they more closely resemble the usual visual discourse of urban design? And to what extent might the value-based planning of Råängen affect the longer-term plans in the wider Brunnshög area?

\subsection{Conditions}

What were the conditions under which Råängen could contemplate a long-term future? Somewhat ironically, a contingent event in the market (Brunnshög) freed them from having to pursue short-term financial interests. The future revenues are projected to be high, and thus Lund Cathedral won "the jackpot," as one observer put it. However, Råängen's engagement with the long term cannot be explained by such contingencies alone. The leadership team consists of a unique combination of financial and practical savviness (a former farmer and a former banker) and theological concerns (a progressive chaplain with a PhD). They were all new to urban planning and had to rely on financial and urban design expertise. Their lack of experience with urban planning did not make them easy to manipulate, however. On the contrary, theology and the values of the church acted as a kind of "mind map," as described by the chaplain, which always leads to reflections on the future role of the church. This process is incremental, but certainly not directionless. Asking open-ended questions about urban planning enabled them to have unprejudiced conversations with the future situation and to consider the values 
that needed to be addressed in the development of the area. As emphasized by the curator, these conversations became "a kind of tool for the church...to think about the values they want to embed in this new neighbourhood" (Architecture Foundation, 2020). These conversations were also set against the timeless purpose and values that reside in the Swedish Church, a deep-time organization that counts engaging with the long term as part of its identity.

\subsection{Interaction between Time Scales}

Given that the Råängen experiment is still in its early stages and few irreversible decisions have yet been made, we could not observe any explicit interactions between different time scales. It is clear that the municipality has both a stronger emphasis on short-term decisions with long-term implications (such as the tramline cutting through Råängen) and an eye to the 'short long term' through a planning horizon of 2040. In the future, more interactions with the Brunnshög process will emerge, a process that declares itself to be "flexible and adaptable to future needs" (Lund Municipality, 2020). Within Råängen, different time scales also need to interact more explicitly. For instance, the cathedral managers imagine that a developer will, at some stage, be awarded a contract that controls the future for a few decades. They will then need to decide how this contract relates to their long-term considerations and tripartite value structure and how to ensure that developers come to accept these values as their own. The story about Råängen, which is gradually being crafted by the artistic commissions and conversations, might enable this, as well as the Hage communal garden that, as the first permanent construction on site, is a manifestation of the kind of value-based urban transformation Lund Cathedral aims for.

\section{Conclusions}

What can planning practice and research learn from Råängen's experiment with planning for the long term? One observation concerns the central role that artistic interventions have played in the conversations thus far. Whereas art in planning processes is often-as Råängen's curator puts it-a kind of 'veneer' laid over decisions about land use and urban design that have already been made, here we saw something different. The art commissions helped to frame the problem and offered a chance to interrogate the values that are so central in this case. Moreover, Coley's interventions in particular were not chiefly interested in engaging the local community, but rather explored the role of the church in the twenty-first century. Coley's approach thus echoes Bishop's (2006) critique of socially engaged art: The collaboration with a community should not be valued over the aesthetic quality of the art work. This resonates with some of our findings: Coley stressed that his artistic inter- ventions have an inherent quality, regardless of who was involved in creating and discussing them. However, we observed that this form of art can also have implications for long-term planning, particularly in the ways those unable to participate are represented. In this case, such interests were geographically and temporally far away (i.e., migrants and future generations), which the church has to engage with in planning for another thousand years. Råängen thus demonstrates the value of two roles of art in planning: The interrogation of ethics during the decision-making process and a type of participation that is less invested in those present than in considering the interests of people elsewhere around the globe or in time. All of this can be related to contemporary sustainability debates about ecological democracy (see, e.g., Eckersley, 2004) and intergenerational equity (e.g., Caney, 2019; World Commission on Environment and Development, 1987).

Another key insight from the Råängen case is that a collaborative reflection on the long term is almost inevitably a conversation about values. There are no clear means and ends in the conversation when the future is so far away. For the period we analyzed empirically (2012-2020), it is important to note that there was a kind of tabula rasa for value reflection-a piece of 'empty' farmland. Such reflections become much harder if, say, residents are demanding concrete improvements to their neighborhood or a sneaky developer is trying to interpret a contract to his advantage. In such situations, reflections about the long term and concomitant values need to be organized much more carefully. Or, in Mische's (2014) words, it might be easier to stage a site of hyper-projectivity around a piece of farmland than around a dense urban area where present interests are well-represented. This challenge, however, does not mean planning should refrain from experiments with the long term in complex situations. Indeed, a deeptime organization like the church might have the financial resources and theological language to do so, but as Hanusch and Biermann (2020) show, there are other kinds of deep-time organizations, such as banks and ecological foundations, that in their practices incorporate long-term concerns in similar ways.

Of particular interest to spatial planning in this case is the notion of irreversibility: Reflection about decisions that cannot be undone and shape cities for a long time. Some urban experiments are reversible, such as the 'living street,' where residential roads are temporarily closed off to car traffic (Bertolini, 2020). In other cases, however, the decisions in an urban experiment are not as easily adaptable. Take, for instance, the experiment of Oosterwold, 4,300 hectares of former farmland near Amsterdam where residents self-build not only their homes, but also the complete infrastructure. While such an approach is obviously fascinating from a legal and planning-theoretical point of view (e.g., Cozzolino, Buitelaar, Moroni, \& Sorel, 2017; Van Straalen, Witte, \& Buitelaar, 2017), it will be almost impossible 
to repurpose that area if different problem definitions and solutions arise in the future. In Råängen, the actors involved are-often implicitly-aware of the fact that it is hard to change tack once building commences, and therefore time for reflection is included in the project as often as possible. The lesson for other urban experiments is that, when the outcomes are irreversible, there is an even greater need to organize reflection and conversations about the long term.

Finally, Råängen can teach us important lessons about how the long-term future can be brought to the present. We observed a plurality of what Pelzer and Versteeg (2019, p. 24) call 'imaginative logics,' defined as "the set of principles underlying or constituting an imaginative intervention, by means of which an abstract phenomenon is made present to the audience." Using their typology, we observed a 'doable' imaginative logic for the financial analyses and the municipal zoning plans, laying out a clear course of action. Most of the artistic interventions can be described as 'guerilla' imaginative logics, attempts to provoke an audience by comparing a church to a migrant shelter or suggesting that heaven might be a boring place. Moreover, throughout the process we observed a 'procedural' imaginative logic, wherein the future is not so much presented externally but as something that people-in this regard mostly the church board-need to imagine themselves. None of these are accompanied by detailed plans, but rather involve continuous conversation with a future situation in which questions are prioritized over answers.

It is all too easy to be cynical about the challenge of experimenting with the long term and discard Råängen as too particular an example. Indeed, the combination of a deep-time organization (the cathedral) and sheer luck (Brunnshög development) is not often found. Yet, there are many other urban experimenters who have some flexibility that allows them to take the long term into account. In his recent book, Krznaric (2020) calls for more long-term thinking. One of the strategies he outlines is cathedral thinking, plotting projects that span generations, such as religious buildings or sewage systems. Urban experiments are by nature different, since they are more versatile and flexible. Yet, the Cathedral of Lund teaches us that this is by no means a reason not to look far ahead and engage with the longer-term futureindeed, an experimental form of cathedral thinking.

\section{Acknowledgments}

This research was conducted as part of the CLIMAGINARIES research project funded by the Swedish Research Council Formas (project no. 2017-01924). The authors wish to extend their thanks to the interviewees for providing us access to the fascinating case of Råängen, to two anonymous reviewers and the Academic Editors for their helpful suggestions, as well as to Edward Jacobson, Paul Graham Raven, Graeme Macdonald, Alexandra Nikoleris, Wytske Versteeg, Lisette van Beek and Ludwig Bengtsson Sonesson for valuable input and comments on earlier versions of the article.

\section{Conflict of Interests}

The authors declare no conflict of interests.

\section{Supplementary Material}

Supplementary material for this article is available online in the format provided by the authors (unedited).

\section{References}

Architecture Foundation. (2020, April 29). 100 day studio: Land in common [Video film]. Retrieved from https://www.youtube.com/watch?v=syHOm-hgIR0

Art and Christianity. (2020, April 20). Jes Fernie: Holy ground lecture for Art and Christianity [Video film]. Retrieved from https://www.youtube.com/watch? $\mathrm{v}=\mathrm{b} 5 \mathrm{ft} L \mathrm{rgP} 4 \mathrm{zw}$

Bendor, R., Maggs, D., Peake, R., Robinson, J., \& Williams, S. (2017). The imaginary worlds of sustainability: Observations from an interactive art installation. Ecology and Society, 22. https://doi.org/10.5751/ES09240-220217

Berman, M. (1983). All that is solid melts into air: The experience of modernity. London: Verso.

Bertolini, L. (2020). From "streets for traffic" to "streets for people": Can street experiments transform urban mobility? Transport Reviews, 40(6), 734-753.

Bishop, C. (2006). The social turn: Collaboration and its discontents. Artforum, 44(6), 178-183.

Brown, H. S., \& Vergragt, P. J. (2008). Bounded sociotechnical experiments as agents of systemic change: The case of a zero-energy residential building. Technological Forecasting and Social Change, 75(1), 107-130.

Bulkeley, H., \& Castán Broto, V. (2012). Government by experiment? Global cities and the governing of climate change. Transactions of the Institute of British Geographers, 38(3), 361-375.

Candy, S., \& Dunagan, J. (2017). Designing an experiential scenario: The people who vanished. Futures, 86 , 136-153.

Caney, S. (2019). Democratic reform, intergenerational justice and the challenges of the long-term. Centre for the Understanding of Sustainable Prosperity. Retrieved from https://cusp.ac.uk/essay/m1-11

Caprotti, F., \& Cowley, R. (2016). Interrogating urban experiments. Urban Geography, 38(9), 1441-1450.

Cozzolino, S., Buitelaar, E., Moroni, S., \& Sorel, N. (2017). Experimenting in urban self-organization: Framework-rules and emerging orders in Oosterwold. Cosmos+ Taxis, 4(2), 49-59.

Dewey, J. (1938). Experience and education. New York, NY: Macmillan.

Eckersley, R. (2004). The green state: Rethinking democ- 
racy and sovereignty. Cambridge, MA: MIT Press.

Evans, J. P. M., Karvonen, A., \& Raven, R. (2016). The experimental city. London: Routledge.

Fernie, J. (2017). Brunnshög commissioning programme art plan (Independent report).

Florida, R. (2002). The rise of the creative class: And how it's transforming work, leisure, community and everyday life. New York, NY: Basic Books.

Fuenfschilling, L., Frantzeskaki, N., \& Coenen, L. (2019). Urban experimentation and sustainability transitions. European Planning Studies, 27(2), 219-228.

Glaeser, E. (2011). Triumph of the city: How urban spaces make us human. London: Pan Macmillan.

Hajer, M. (2009). Authoritative governance: Policymaking in the age of mediatization. Oxford: Oxford University Press.

Hajer, M., \& Zonneveld, W. (2000). Spatial planning in the network society-rethinking the principles of planning in the Netherlands. European Planning Studies, 8(3), 337-355.

Hanusch, F., \& Biermann, F. (2020). Deep-time organizations: Learning institutional longevity from history. The Anthropocene Review, 7(1), 19-41.

Haynes, C. (2018). Heaven is in the east: How sacred architecture plays with time. Råängen. Retrieved from https://konst.raangen.se/programme/cathyhaynes

Healey, P. (1992a). Planning through debate: The communicative turn in planning theory. Town Planning Review, 63(2), 143-162.

Healey, P. (1992b). A planner's day: Knowledge and action in communicative practice. Journal of the American Planning Association, 58(1), 9-20.

Healey, P. (2009). The pragmatic tradition in planning thought. Journal of Planning Education and Research, 28(3), 277-292.

Hillier, J., \& Healey, P. (Eds.). (2010). The Ashgate research companion to planning theory: Conceptual challenges for spatial planning. Farnham: Ashgate.

Hoch, C. (1994). What planners do: Power, politics, and persuasion. Chicago, IL: American Planning Association.

Hoch, C. (2016). Utopia, scenario and plan: A pragmatic integration. Planning Theory, 15(1), 6-22.

Kronsell, A., \& Mukhtar-Landgren, D. (2018). Experimental governance: The role of municipalities in urban living labs. European Planning Studies, 26(5), 988-1007.
Krznaric, R. (2020). The good ancestor: How to think longterm in a short-term world. London: WH Allen.

Lund Municipality. (2020). Brunnshög project. Lund Municipality. Retrieved from https://www.lund.se/ en/brunnshog/about/project-phases

Markard, J., Raven, R., \& Truffer, B. (2012). Sustainability transitions: An emerging field of research and its prospects. Research Policy, 41(6), 955-967.

Mische, A. (2014). Measuring futures in action: Projective grammars in the Rio+ 20 debates. Theory and Society, 43(3/4), 437-464.

Pelzer, P., \& Versteeg, W. (2019). Imagination for change: The post-fossil city contest. Futures, 108, 12-26.

Råängen. (2020). Commissions. Råängen. Retrieved from https://art.raangen.se/commissions

Schön, D. A. (1983). The reflective practitioner. New York, NY: Basic Books.

Schön, D. A. (1992). The theory of inquiry: Dewey's legacy to education. Curriculum Inquiry, 22(2), 119-139.

Scott, J. C. (1998). Seeing like a state: How certain schemes to improve the human condition have failed. New Haven, CT: Yale University Press.

Sengers, F., Wieczorek, A. J., \& Raven, R. (2019). Experimenting for sustainability transitions: A systematic literature review. Technological Forecasting and Social Change, 145, 153-164.

Sommar, I. (2018, May 28). Kyrkans stadsplanering är vad Sveriges bostadsmarknad behöver [The Church's urban planning is what the Swedish housing market needs]. Sydsvenskan. Retrieved from https://www.sydsvenskan.se/2018-05-28/ingridsommar-kyrkans-stadsplanering-ar-vad-sverigesbostadsmarknad-behover

Sorensen, A. (2015). Taking path dependence seriously: An historical institutionalist research agenda in planning history. Planning Perspectives, 30(1), 17-38.

Torrens, J., Schot, J., Raven, R., \& Johnstone, P. (2019). Seedbeds, harbours, and battlegrounds: On the origins of favourable environments for urban experimentation with sustainability. Environmental Innovation and Societal Transitions, 31, 211-232.

Van Straalen, F. M., Witte, P., \& Buitelaar, E. (2017). Self-organisation in Oosterwold, Almere: Challenges with public goods and externalities. Tijdschrift voor economische en sociale geografie, 108(4), 503-511.

World Commission on Environment and Development. (1987). Our common future. Oxford: Oxford University Press.

\section{About the Authors}

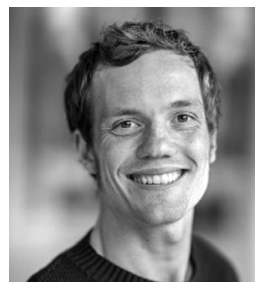

Peter Pelzer is an Assistant Professor in Spatial Planning and Urban Futures at the Department of Human Geography and Spatial Planning and is affiliated with the Urban Futures Studio, both at Utrecht University, The Netherlands. He is fascinated by how we imagine and achieve sustainable urban futures. This interest has led him to various realms such as computer models, artistic and designerly practices, urban mobility and sustainable neighborhoods. 


\section{COGITATIO}

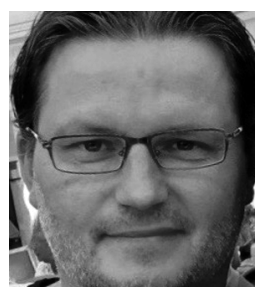

Roger Hildingsson is a Senior Researcher in Political Science at Lund University, Sweden. His research focuses on environmental politics, sustainability governance and the governing of climate change at various sites, as well as on the green state, urban sustainability, industrial decarbonisation, and the transition to post-fossil futures. His works is published in a number of edited volumes and journals such as Environmental Politics, Environmental Policy and Governance and Futures.

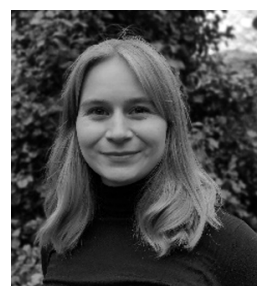

Alice Herrström (MA) is a Graduate Student in Political Science, Lund University, Sweden. She has acted as a Research Assistant in the CLIMAGINARIES research project with responsibility for coordinating the Råängen study as well as conducting the literature review on urban experimentation informing this article.

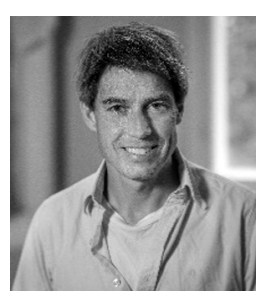

Johannes Stripple is an Associate Professor in Political Science at Lund University, Sweden. His research has traced the governance of climate change through a range of sites, from the UN to the everyday, from the economy, the urban, and the low carbon self. He has edited Governing the Climate: New Approaches to Rationality, Power and Politics (Cambridge University Press, 2014) and Towards a Cultural Politics of Climate Change (Cambridge University Press, 2016). 